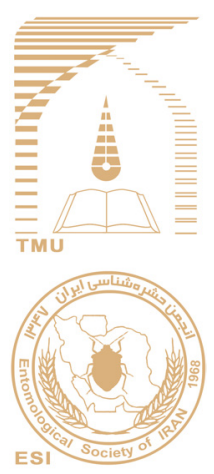

\section{Two new records of the genus Icerya Signoret, 1875 (Hemiptera, Coccomorpha, Monophlebidae) from Oman}

\author{
Ali A. Al-Jahdhami ${ }^{*}{ }^{*}$, Said Al-Rashdi2 ${ }^{(-)}$\& Mansoor Al-Jahdhami ${ }^{3}$ \\ 1 Ministry of Agriculture and Fisheries Wealth, Department of Plant Protection, Samad Ashan, Sultanate of \\ Oman.entomologistali96@gmail.com \\ 2 National center for research, Muscat, Alkhwair, Sultante of Oman. S-alrashdi@outlook.com \\ 3 Office for Conservation of the Environment, Muscat, Alkhwair, Sultante of Oman. mhjahdhami@gmail.com
}

\begin{abstract}
Two species of the family Monophlebidae (Hemiptera: Coccomorpha) are recorded for the first time in Oman. Icerya purchasi and Icerya seychellarum are occurred in northern Oman in Al-Jabel Al Akhdher while Icerya aegyptiaca is occurred in South Oman in Dhofar. Icerya purchasi and I. seychellarum are caused considerable damage on Punica granatum, Juglans regia, Ziziphus spina, Ficus carica, Acacia sp and Nerium oleander. The populations of the I. purchasi and I. seychellarum were considered to be exotic pests rather than aggressive native pest. These new records will be useful in the future as it could establish a solid area for researchers who will be interested to know about this species or the relation between these species with other species either from same species type or different species from other genera that could be reported in the future.
\end{abstract}

Key words: Icerya purchasi, Icerya seychellarum, Icerya aegyptiaca, Oman, new records

Subject Editor:

Ján Kollár

Citation: Al-Jahdhami, A.A., Al-Rashdi, S. \& Al-Jahdhami, M. (2021) Two new records of the genus Icerya Signoret, 1875 (Hemiptera, Coccomorpha, Monophlebidae) from Oman. Journal of Insect Biodiversity and Systematics, 7 (1), 59-65.

\title{
Introduction
}

The genus Icerya Signoret, 1875 of the tribe Icerini Cockerell, 1899 belonging to the family Monophlebidae Morrison, 1928 (Hemiptera: Coccomorpha) (Unruh \& Gullan, 2008b). There are 35 species in the world are included in this genus and commonly known as fluted scales because of the fluted appearance of the ovisac (Moghaddam, et al, 2015). Most species of the family Monophlebidae being relatively polyphagous (Ben-Dov, 2005). Some iceryine species when introduced to new areas without their adapted natural enemies could proliferate and become serious plant pests (Kondo et al., 2016), for example, Icerya aegyptiaca (Douglas) in the Ryukyu Islands (Japan) (Uesato et al., 2011). Icerya purchasi Maskell has been introduced into other parts of the world through global trade in California (USA) on Acacia plants around 1868 or 1869 (Kollár et al., 2016). Icerya aegyptiaca is so common and so widely distributed in Afrotropical, Australasian, Oriental and Palaearctic, and probably is imported from the southeast borders (Watson \& Malumphy, 2004). Unruh \& Gullan (2008a, 2008b) suggested that $I$. aegyptiaca is native to either the Australasian or the Indo-Malayan biogeographic regions and I. purchasi is native to Australia or New Zealand.

Corresponding author: Ali A. Al-Jahdhami, E-mail: entomologistali96@gmail.com

Copyright (c) 2021, Al-Jahdhami et al. This is an open access article distributed under the terms of the Creative Commons Attribution License (CC BY 4.0), which permits unrestricted use, distribution, and reproduction in any medium, provided the original author and source are credited. 
Rodolia cardinalis (Mulsant) (Coleoptera: Coccinellidae) has successfully reduced I. purchasi populations in many countries (Caltagirone \& Doutt, 1989). Some trials were also conducted for colonizing the parasitic fly Cryptochetum iceryae Williston (Diptera: Cryptochetidae with cotton cusion scale. Both of these natural enemies showed high efficiency in the control of the cottony cushion scale due to their short generation time (4-6 weeks) and host specificity, attacking only the cottony cushion scale (Grafton-Cardwell \& Flint, 2003).

The presented species in Oman in this paper is necessarily uncompleted, because most the specimens collected from few locations in South and North of Oman as well as with limited methods used in collection. However, the goal of this paper is the further faunistic study on Monophlebidae of Oman. Here we review all the available material of Monophlebidae, reporting three species; two of them are being new records for Oman.

\section{Material and methods}

The specimens of I.purchasi were collected from private citizens farms and some wild plants from three villages in Al-Jabel Al Akhadher (Wadi beni habeeb, Sayq and Al-Manakher) on Punica granatum, Juglans regia, Ziziphus spina, Ficus carica, Acacia sp. and Nerium oleander. The I. seychellarum were also collected from private citizens' farms in one location in Al-Jabel Al Akhadher (Wadi beni habeeb) on Juglans regia, Psidium guajava and Punica granatum. The locality Al-Jabel Al Akhdher is situated in the Ad Dakhiliyah Governorate and it is part of the Al Hajar Mountains range with high land $(2950 \mathrm{~m})$. The typical climate of Al-Jabel Al AKhadher is characterized as warm, moderately dry with mild winter. The average annual temperature of 5$15^{\circ} \mathrm{C}$ and annual average precipitation of 10-48 $\mathrm{mm}$ (1986-2009).

Icerya aegyptiaca were collected in Dhofar (Ein Hamran) on Prosopis juliflora and from private house garden on Boswellia sacra. The locality Ein Hamran is situated in Dhofar Governorate and it is part of the Dhofar Mountains. The typical climate of Ein Hamran is characterized as warm with mild winter. The average annual temperature of $19-27^{\circ} \mathrm{C}$ and annual average precipitation of 1-25 mm (1986-2009).

The identification key of adult females was based in the identification guide to species of the scale insect tribe Iceryini (Coccoidea: Monophlebidae) by Unruh \& Gullan (2008b). The damage level on the host plants was evaluated according to the count of adult female individuals.

\section{Results}

In this research, three species of the family Monophlebidae are recorded form Oman, of which Icerya purchasi and Icerya seychellarum are new records for the fauna of Oman.

\section{Monophlebidae Signoret, 1875}

Icerya Signoret, 1875

\section{Icerya purchasi Maskell, 1878 (Fig. 1)}

Examined specimens: Nizwa, Al-Jabel Al-Akhadhar, Seiq, 50우, 20.Viii.2017; Nizwa, AlJabel Al-Akhadhar, Wadi beni habib, 42우, 20-30.Viii.2017; Nizwa, Al-Jabel Al-Akhadhar, Al-Manakher, 12+o, 20-30.Viii.2017, leg.: A. Al-Jahdhami.

Biological notes: The cottony cushion scale can be easily distinguished from other scale insects. The mature females (hermaphrodites) have bright orange-red, yellow, or brown bodies (Ebeling, 1959). The body is partially or entirely covered with yellowish or white 
wax. The most observed feature is the fluted egg sac, which frequently to be about 2.5 times longer than the body. The egg sac contains around 1000 red eggs (Gossard, 1901).

Males are winged with a dark red body and dark colored antennae and they are rare. Dark whorls of setae extend from each antennal segment, except the first (Ebeling, 1959). It is interesting that the female is always a hermaphrodite with both testes and ovaries. If selffertilization occurs, just hermaphrodites are produced. However, Ebeling (1959) reported that when a hermaphrodite mate with a male, more males and hermaphrodites are produced.

Regarding the effects of temperature, eggs need a few days to two months to hatch. The newly hatched nymphs are bright red along with dark antennae and brown legs. The antennae are six-segmented. This is the primary dispersal stage. Nymphs can move to new locations by wind, crawl to nearby plants. The adult begins to deposit eggs after three molts and secretes the conspicuous egg sac. As the egg sac is formed, the scale's abdomen becomes more tilted until the scale appears to be standing on its head (Kollár et al., 2016).

Host plants in Oman: Icerya purchasi is most frequently collected on Punica granatum (Lythraceae), Juglans regia (Juglandaceae), Ziziphus spina (Rhamnaceae), Ficus carica (Moraceae), Acacia sp (Fabaceae), Nerium oleander (Apocynaceae) and other wild plants in Al-Jabel Al Akhdhar.

Distribution in Oman: The species is so far known only from Al-Jabel Al Akdhar (Wadi beni habib, Al-Manakher, Saeiq)

General Distribution: It is distributed in 126 countries around the world (Liu \& Shi, 2020).

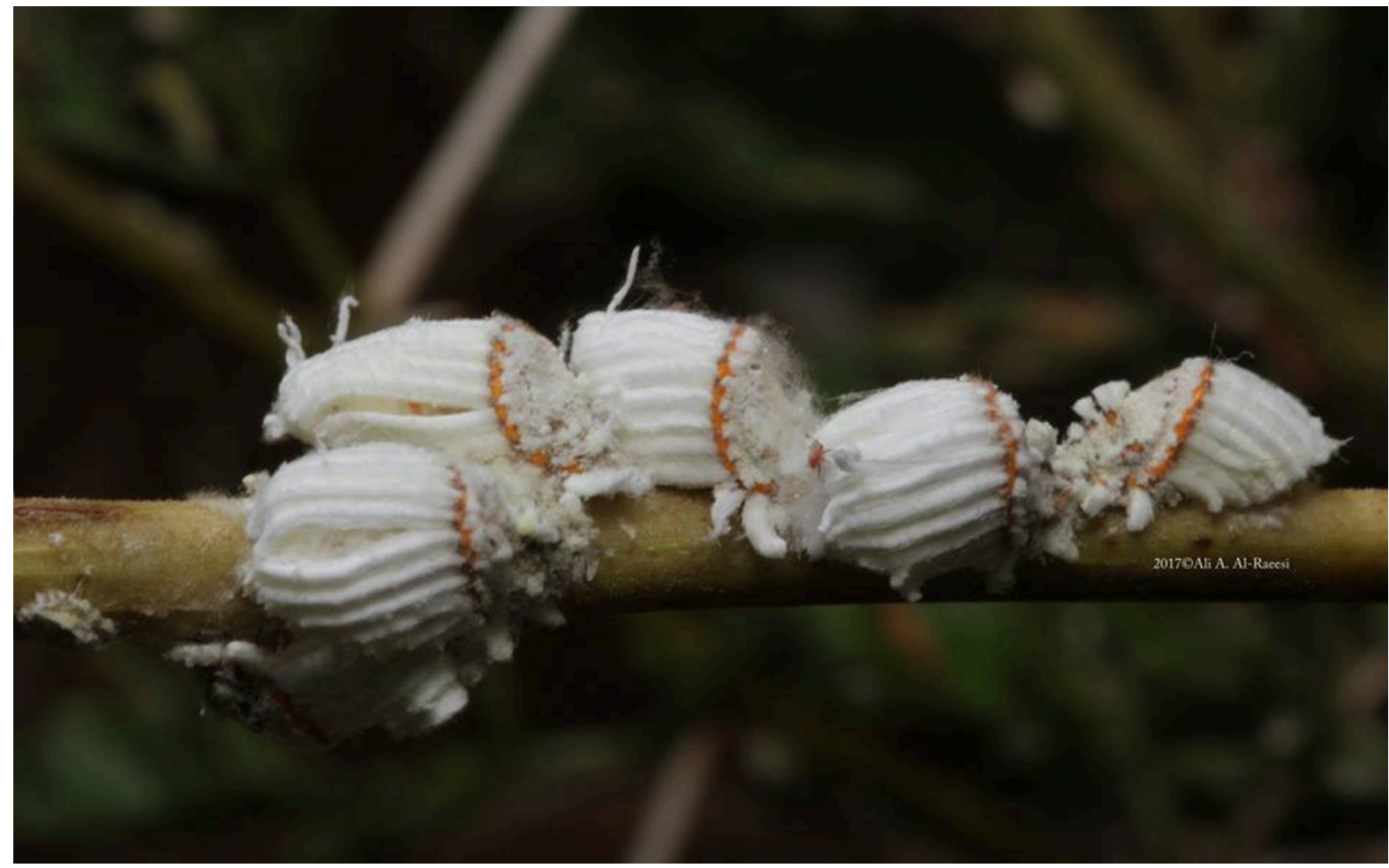

Figure 1. Female cottony cushion scale Icerya purchasi Maskell (Hemiptera, Coccomorpha, Monophlebidae) in Oman. 
Icerya aegyptiaca (Douglas, 1890)

Examined specimens: Dhofar, Ain Hamran, 11우, 5-10.xi.2017, leg.: A. Al-Jahdhami.

Biological notes: Dorsum of adult female covered in wax, with long waxy extensions marginally and longer at anterior end. The posterior tassels covering ovisac, giving it a fluted appearance.

Host plants in Oman: Icerya aegyptiaca is most frequently collected on Boswellia sacra (Burseraceae) and Prosopis juliflora (Fabaceae).

Distribution in Oman: The species is so far known only from Dhofar (Ain Hamran).

General Distribution: It is widely distributed in tropical and subtropical regions (Liu \& Shi, 2020).

Icerya seychellarum (Westwood, 1855) (Fig. 2)

Examined specimens: Nizwa, Al-Jabel Al-Akhadhar, Wadi beni habib, 15우, 2030.Viii.2017, leg.: A. Al-Jahdhami.

Biological notes: Adult female usually with 11-segmented antennae. The dorsal body with transverse rows of white to yellowish waxy secretion and marginal tufts; glassy filaments projecting from margins and medial dorsum; ovisac projecting from posterior end of body, covered dorsally by a series of long, cylindrical waxy tassels.

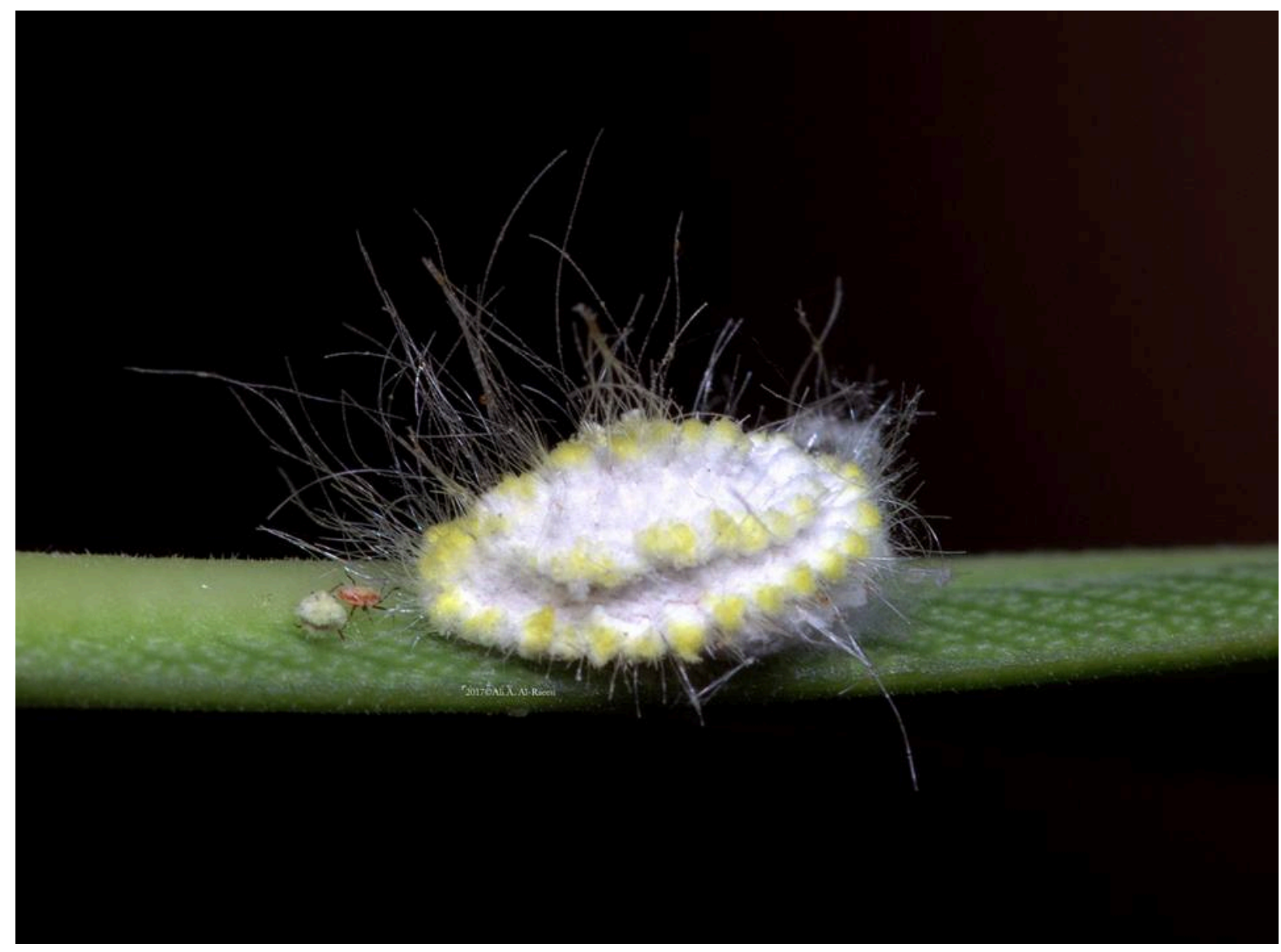

Figure 2. Female Icerya seychellarum (Westwood) (Hemiptera, Coccomorpha, Monophlebidae) in Oman. 
Host plants in Oman: Icerya seychellarum is most frequently collected on Juglans regia (Juglandaceae), Psidium guajava (Myrtaceae) and Punica granatum (Lythraceae).

Distribution in Oman: The species is so far known only from Al-Jabel Al Akdhar (Wadi beni habib).

General Distribution: It is distributed in tropical and subtropical areas and is recorded South-East Asia, Africa, Southern Europe and Australia (García Morales et al., 2016).

\section{Discussion}

The cottony cushion scale I. purchasi and the Egyptian icerya, I. aegyptiaca are most important Icerya species with powerful invasiveness (Liu \& Shi, 2020). Icerya purchasi is reported from 78 families and 190 genera of plants, I. aegyptiaca is reported from 59 families and 113 genera of plants, I. seychellarum is reported from from 58 families and 128 genera of plants (García Morales et al., 2016). They are pests of several ornamentals and crops in Oman, such as Punica granatum, Juglans regia, Ziziphus spina, Ficus carica, Acacia sp., Nerium oleander and Boswellia sacra. The host range of I.purchasi was wide and it is considered to be more aggressive than I. seychellarum and I. aegyptiaca. Icerya purchasi represents one of the most important examples of successful biological control through the release of the predator Rodolia cardinalis (Mulsant) (Coleoptera: Coccinellidae) (Lo Verde et al., 2020). A predacious ladybird beetle of the Rodolia argodi was observed feeding on I. aegyptiaca in Dhofar area. Single specimen of $R$. argodi was collected from vegetation in Al-Jabel Al AKhadher and this gives indication of preying. The populations of the I. purchasi and I. seychellarum were considered to be exotic pests by introducing infected plants rather than aggressive native pest as there were no records or observation in Oman. The I. purchasi and I. seychellarum should be reported as the first record in Oman as they have infecting economically important crops and plants.

\section{Acknowledgments}

We would like to acknowledge Ali Al-Raeesi for the photos. Thanks extend to the Sultan Qaboos University (Entomology department) for facilitating lab equipment use. We also thank to Dr. Adel Al-Shihi (Head of Locust control center) for his help in paper review.

\section{Conflict of Interests}

The authors declare that there is no conflict of interest regarding the publication of this paper.

\section{ORCID}

Ali A. Al-Jahdhami: https:/ / orcid.org/0000-0003-1204-0491

Said Al-Rashdi: https:/ / orcid.org/0000-0002-6042-0002

Mansoor Al-Jahdhami: https:/ / orcid.org/0000-0003-2076-8204

\section{References}

Ben-Dov, Y. (2005) A Systematic Catalogue of the Scale Insect Family Margarodidae (Hemiptera: Coccoidea) of the World. Intercept Limited; Wimborne, UK. 400 pp.

Caltagirone, L.E. \& Doutt, R.L. (1989) The history of the vedalia beetle importation to California and its impact on the development of biological control. Annual Review of Entomology, 34, 1-16. https://doi.org/10.1146/annurev.en.34.010189.000245

Ebeling, W. (1959) Subtropical Fruit Pests. Los Angeles, University of California Press. 
García Morales, M., Denno, B.D., Miller, D.R., Miller, G.L., BenDov, Y. \& Hardy, N.B. (2016) ScaleNet: A literature-based model of scale insect biology and systematics. Database, 2016, 1-5. https://doi.org/10.1093/database/bav118

Gossard, H.A. (1901) The cottony cushion scale. Florida Agricultural Experiment Station Bulletin, 56, 309-356.

Grafton-Cardwell, E.E. \& Flint, M.L. (2003) Pest notes: Cottony Cushion Scale - Integrated Pest Management for Home Gardeners and Landscape Professionals. Pub. 7410. University of California, Agriculture and Natural Resources.

Kollár, J., Bakay, L. \& Pástor, M. (2016) First record of the cottony cushion scale Icerya purchasi (Hemiptera, Monophlebidae) in Slovakia. Plant Protection Science, 52, 217-219. https://doi.org/10.17221/23/2016-PPS

Kondo, T., Gullan, P. J., Peronti, L. B. G., Ramos-Portilla, A. A., Caballero, A. \& Villarreal-Pretelt, N. (2016) First records of the iceryine scale insects Crypticerya brasiliensis (Hempel) and Crypticerya genistae (Hempel) (Hemiptera: Monophlebidae) for Colombi. A Journal of World Insect Systematics, 0480, 1-9.

Lo Verde, G., Cerasa, G., Altamore, B. \& Farina, V. (2020) First record of Icerya seychellarum and confirmed occurrence of Aulacaspis tubercularis (Hemiptera: Coccomorpha) in Italy. Phytoparasitica, 48, 175-182. https://doi.org/10.1007/s12600-020-00792-w

Liu, Y. \& Shi, J. (2020) Predicting the Potential Global Geographical Distribution of Two Icerya Species under Climate Change. Forests, 11, 684. https://doi.org/10.3390/f11060684

Moghaddam, M., Esfandiari, M. \& Khosravi, M. (2015) First record of Icerya aegyptiaca (Hemiptera: Coccoidea: Monophlebidae) from Iran. Proceedings of the 1st Iranian International Congress of Entomology, 2015, 29 - 31 August, Tehran, Iran. Ministry of Agriculture, Tehran, pp. 4-5.

Papadopoulou, S. \& Chryssohoides, C. (2012) Icerya purchasi (Homoptera: Margarodidae) on Rosmarinus officinalis (Lamiaceae), a new host plant record for Greece. EPPO Bulletin, 42, 148-149. https://doi.org/10.1111/j.1365-2338.2012.02535.x

Uesato, T., Kondo, T., Unruh C. \& Williams D. J. (2011) Establishment and host records of Icerya aegyptiaca (Douglas) (Hemiptera: Coccoidea: Monophlebidae) in the Sakishima islands in the Ryukyu Archipelago, Japan, with notes on its World Distribution. Entomological Science, 14, 4977. https://doi.org/10.1111/j.1479-8298.2010.00411.x

Unruh, C. M. \& Gullan, P. J. (2008a) Molecular data reveal convergent reproductive strategies in iceryine scale insects (Hemiptera: Coccoidea: Monophlebidae), allowing the re-interpretation of morphology and a revised generic classification. Systematic Entomology, 33, 8-50. https://doi.org/10.1111/j.1365-3113.2007.00404.x

Unruh, C. M. \& Gullan, P. J. (2008b) Identification guide to the scale insect tribe Iceryini (Coccoidea: Monophlebidae). Zootaxa, 1803, 1-106. https://doi.org/10.11646/zootaxa.1803.1.1

Watson, G.W. \& Malumphy, C.P. (2004) Icerya purchasi Maskell, cottony cushion scale (Hemiptera: Margarodidae), causing damage to ornamental plants growing outdoors in London. British Journal of Entomology and Natural History, 17, 105-109. 
(Hemiptera, Coccomorpha, Monophlebidae) Icerya Signoret, 1875 دو كزارش جديد از جنس از عمان

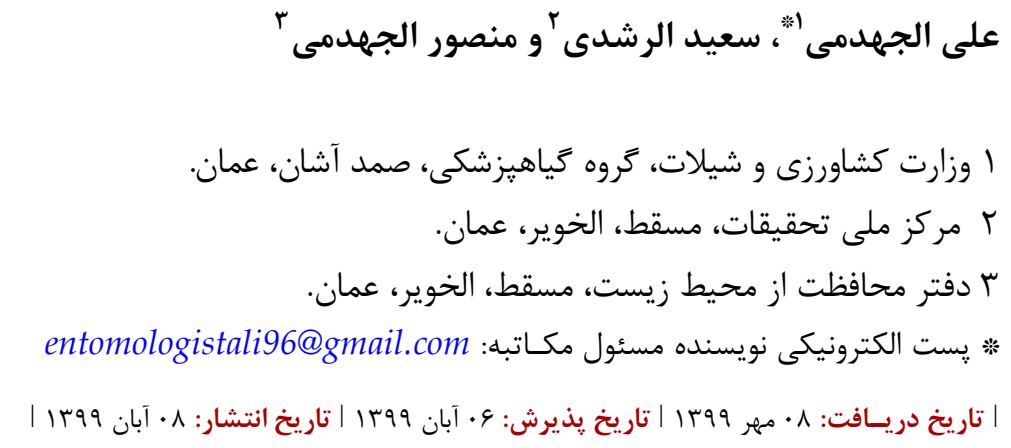

קكيـده: دو كونه از خانواده Hemiptera: Coccomorpha) Monophlebidae) براى

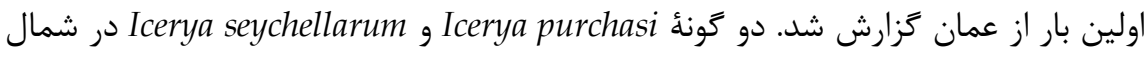
عمان و جبل اخضر يافت شدند، در حالى كه كونه Icerya aegyptiaca

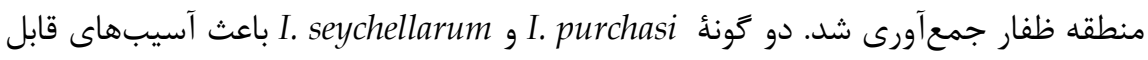

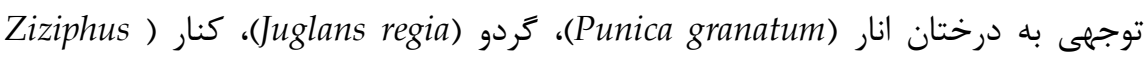

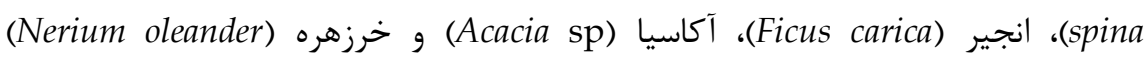

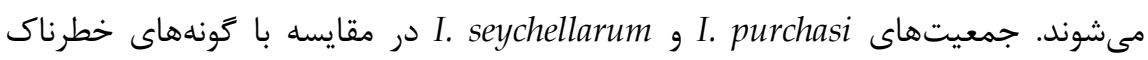

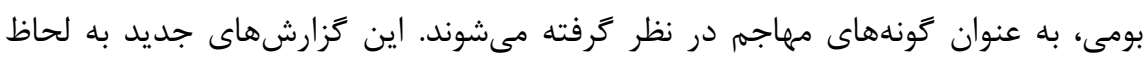

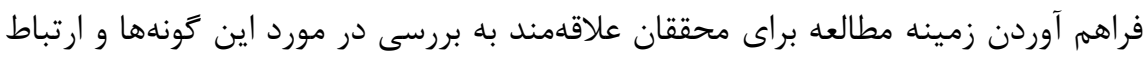

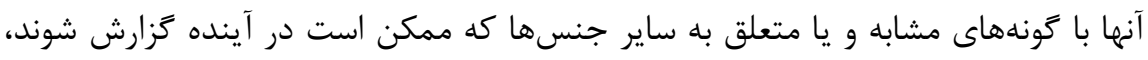
مفيد هستند.

وازَّـان كليدى: Icerya purchasi ، Icerya aegyptiaca ،eychellarum ، عمان، كزارشهاى جديد 